\title{
Supplementary approaches in
}

\section{endodontic retreatment}

\author{
Emilia Karova ${ }^{1}$, Violeta Dogandzhiyska', Irina Tsenova-Ilieva', \\ Miriana Raykovska ${ }^{2}$, Sherihan Zongova-Adem ${ }^{3}$
}

1. Department of Conservative Dentistry, Faculty of Dental Medicine, Medical University, Sofia, Bulgaria;

2. Dentist, Dental Studio 32, Private Dental Practice, Sofia, Bulgaria;

3. Center of Integrated Dental Medicine, Faculty of Dental Medicine, Medical University, Sofia, Bulgaria.

\begin{abstract}
Introduction: The proper cleaning and reshaping of the root canal space is of great importance for the good outcome of the retreatment case. None of the different methods and instruments used for filling material removal during endodontic retreatment exhibit 100\% effectiveness. Aim: The aim of the current review article is to observe the contemporary supplementary approaches used in endodontic retreatment. Materials and Methods: Articles within the last 10 years were reviewed in light of the most commonly used supplementary techniques. Conclusion: Supplementary approaches show sophisticated results in filling remnants removal which leads to a better outcome of the endodontic retreatment cases.
\end{abstract}

Keywords: Endodontic retreatment, Supplementary techniques, lasers

\section{Introduction}

Orthograde retreatment is considered the first option in case of a failed primary endodontic treatment. The procedure includes removal of the old filling material and secondary shaping and disinfection of the root canals for achieving better conditions for hermetic root canal sealing and enabling the tooth preservation. (1). 
Different retreatment techniques are described in the literature. Nickel-titanium (NiTi) rotary instruments are preferably used in these cases due to their superelasticity and flexibility (2). Systems, specifically developed for endodontic retreatment, like Mtwo Retreatment (VDW, Munich, Germany), D-Race (FKG, La Chaux de Fonds, Switzerland), Protaper Universal Retreatment (Dentsply, Ballaigues, Switzerland), R Endo (MicroMega, Besancon, France), etc., have been introduced to the market. They improve significantly the filling material removal from the root canal walls, compared to the manual instruments $(3,4)$. Similar effectiveness was registered in experiments with conventional NiTi instruments driven by continuous or reciprocating rotation $(5,6)$.

The complex anatomy of the endodontic system is one of the main factors that influence the positive outcome of the retreatment procedure. Most experimental investigations, concerning endodontic retreatment, are focused on teeth with oval-shaped root canals. Because of the non-adaptive core of the standard $\mathrm{NiTi}$ instruments and their ability to move in the center of the canal, a large area of the oval-shaped canals remains untouched from the files $(7,8)$. The up-to-date literature states that the clean root canal surface following orthograde retreatment procedures is not more than $40 \%$ and thus, additional cleaning of the canal walls is required $(9,10,11)$.

\section{Review Results}

The recently developed systems XP-Endo Finisher and the specifically designed for retreatment XP-Endo Finisher $\mathrm{R}$ are stated to have favorable effect as additional cleaning instruments after the bulk material has been initially removed.

XP-Endo Finisher and XP-Endo Finisher R (FKG Dentaire, La Chaux de Fonds, Switzerland) are novel instruments made of superelastic, NiTi MaxWire (Martensite-Austenite Electropolish FleX alloy). The flexibility of the instruments is a result of the heating of the alloy during the manufacturing process. These files acquire a "spoon-like" shape, $10 \mathrm{~mm}$ of the tip due to their martensite-austenite transformation when exposed to body temperature. The acquired shape allows the instrument to reach the anatomical irregularities of the root canal that are inaccessible for the conventional NiTi instruments. Both XP-Endo Finisher (size 25) and XP- Endo Finisher R (size 30) instruments have a taper close to zero (.01 taper in Mphase and .04 taper in Austenitic phase) (11).

Current studies demonstrate that XP-Endo Finisher and XP-Endo Finisher $\mathrm{R}$ enhance the cleaning of the root canal walls from debris and/or filling materials $(10,12,13,14)$. Crozeta et al. applied in their study XPEndo Finisher $\mathrm{R}$ and an ultrasonic tip as supplementary steps in the retreatment of oval-shaped canals filled with Gutta-percha and two different types of sealers (AH Plus or BC Sealer). They compared the efficacy of the two techniques in the removal of the root filling materials and concluded that the ultrasonic tip is equally effective in removing both types of sealers, while XP-Endo Finisher R removes AH Plus sealer better than BC Sealer (15). On the other hand, H.Aksel et al. reported that XP-Endo Finisher significantly improves the removal of root filling, regardless of the sealer used (16). XP-Endo Finisher $R$ is documented to have superior cleaning ability than solvents (17) and ultrasonic and sonic techniques (18).

Self-Adjusting file (SAF), passive ultrasonic irrigation (PUI), ultrasonic tips, sonic devices, etc. have been investigated for their effectiveness as supplementary methods in removing filling materials.

The Self-Adjusting file system (ReDent, Ra'anana, Israel) tested by Abramovitz et al. demonstrated satisfying results in the cleaning of root canal walls from the residue after the use of ProTaper Universal Retreatment (9). This is in accordance with another study in which SAF was used in combination with the ProFile system (19). Yürüker et al. came to the opposite conclusion. They found that the use of SAF as an 
additional instrument did not significantly improve the removal of the filling material compared to the single use of ProTaper Universal Retreatment (20).

Passive ultrasonic irrigation or ultrasonic-assisted irrigation (UAI) are originally developed to clean the smear layer from the root canals. Their action is due to the acoustic streaming and cavitation caused by the vibration of an ultrasonic tip inserted $2 \mathrm{~mm}$ shorter than the working length (WL) at a frequency of $30 \mathrm{kHz}$. (18). Reports in literature state that PUI improves the cleaning of filling remnants when used after the mechanical instrumentation of the root canal $(21,22,23)$.

Ultrasonic tips, especially those designed for supplementary cleaning of oval-shaped canals during retreatment, have been recently examined (24). They tend to improve significantly the removal of filling remnants after the bulk of the material has been removed. Some of the investigated ultrasonic tips proved to be appropriate for cleaning of BC Sealers (15).

Lasers were first introduced in 1959 and since then, they have been used in many aspects of the contemporary dentistry. In the field of endodontics they are applied for root canal debridement and disinfection $(25,26)$. Nd:YAG laser and Er:YAG lasers have been recently tested for root filling removal, relying on the thermal effect of the lasers' irradiation (27).

$\mathrm{Nd}$ :YAG laser is reported to remove filling materials effectively but with substantial rise of the temperature in the surrounding tissues, including blockage of the dentin tubules by melted dentin and carbonization. Viducić $\mathrm{D}$. et al. concluded that Nd:YAG laser is capable of softening gutta-percha. Due to the temperature increase they suggested the use of lower energy parameters and shorter periods of lasing for preserving the periodontal ligament (28). Carbonization disturbs the connection between the new obturation material and the dentin in the root canal, thus worsening the prognosis of the retreatment case (29). Lately, a newlydeveloped fiber-optic system of Nd:YAG enables the laser use even in narrow root canals (28).

Er:YAG laser is preferred for its lower thermal effect on the tooth structures and the surrounding periodontium and its lower thermal trauma compared to Nd:YAG laser (26). In a current study of Tachinami and Katsuumi three different energy output levels of the Er:YAG irradiation were tested and it was concluded that the $40 \mathrm{~mJ}$ energy output is the optimal parameter for gutta-percha removal.

\section{Conclusion}

Supplementary approaches have been investigated to improve the root canal cleaning after the use of rotary instruments and have shown sophisticated results. Innovative NiTi instruments, ultrasonic tips designed for retreatment or activation of the endodontic solutions have been studied and all of them improved the removal of the root filling materials. Lasers have been recently promoted in the field of endodontic retreatment. Development of new additional approaches need to be further investigated to facilitate the prognosis of the endodontic retreatment and relieve daily dental practice.

\section{References}

1. Virdee S S, Thomas M B M. A practitioner's guide to gutta-percha removal during endodontic retreatment. Br Dent J. 2017 Feb 24;222(4):251-257.

2. Karova E. Nickel-titanium Rotary instruments - a guide for students. Sofia, Valdex LTD, 2015.

3. Kfir A, Tsesis I, Yakirevich E, Matalon S, Abramovitz I. The efficacy of five techniques for removing root filling material: microscopic versus radiographic evaluation. Int Endod J. 2012 Jan;45(1):35-41.

4. Patil A, Mali S, Hegde D, Jaiswal H, Saoji H, Edake DN. Efficacy of Rotary and Hand Instrument in removing Gutta-percha and Sealer from Root Canals of Endodontically Treated Teeth. J Contemp Dent Pract. 2018 Aug 1;19(8):964-968. 
5. Martins MP, Duarte MAH, BC, Kato AS, Bueno CES. Effectiveness of the ProTaper Next and Reciproc Systems in Removing Root Canal Filling Material with Sonic or Ultrasonic Irrigation: A Micro-computed Tomographic Study. J Endod. 2017 Mar;43(3):467-471.

6. Rios Mde A, Villela AM, Cunha RS, Velasco RC, De Martin AS, Kato AS et al.Efficacy of 2 reciprocating systems compared with a rotary retreatment system for gutta-percha removal. J Endod. 2014 Apr;40(4):543546.

7. Borges MMB, Duque JA, Zancan RF, Vivan RR, Bernardes RA, Duarte MAH. Efficacy of reciprocating systems for removing root filling material plus complementary cleaning methods in flattened canals: Microtomography and scanning electron microscopy study. Microsc Res Tech. 2019 Jul;82(7):1057-1064.

8. Dhaimy S, Kim H-C, Bedida L, Benkiran I. Efficacy of reciprocating and rotary retreatment nickel-titanium file systems for removing filling materials with a complementary cleaning method in oval canals. Restor Dent Endod. 2021 Feb 3;46(1):e13.

9. Abramovitz I, Relles-Bonar S, Baransi B, Kfir A. The effectiveness of a self-adjusting file to remove residual gutta-percha after retreatment with rotary files. Int Endod J. 2012 Apr;45(4):386-392.

10. Alves FRF, Marceliano-Alves MF, Sousa JCN, Silveira SB, Provenzano JC, Siqueira Jr JF. Removal of Root Canal Fillings in Curved Canals Using Either Reciprocating Single- or Rotary Multi-instrument Systems and a Supplementary Step with the XP-Endo Finisher. J Endod. 2016 Jul;42(7):1114-1119.

11. Baranwal HC, Singh N, Kumari A. XP Endo File: An Update Review. Indian J Dent Sci 2020; 12:53-55.

12. Silva EJNL, Belladonna FG, Zuolo AS, Rodrigues E, Ehrhardt IC, Souza EM et al. Effectiveness of XPendo Finisher and XP-endo Finisher $\mathrm{R}$ in removing root filling remnants: a micro-CT study. Int Endod J. 2018 Jan;51(1):86-91.

13. De-Deus G, Belladonna FG, Zuolo AS, Cavalcante DM, Carvalhal JCA, Simões-Carvalho M et al.XP-endo Finisher $\mathrm{R}$ instrument optimizes the removal of root filling remnants in oval-shaped canals. Int Endod J. 2019 Jun;52(6):899-907.

14. Karamifar K, Mehrasa N, Pardis P, Saghiri MA. Cleanliness of Canal Walls following Gutta-Percha Removal with Hand Files, RaCe and RaCe plus XP-Endo Finisher Instruments: A Photographic in Vitro Analysis. Iran Endod J. Spring 2017;12(2):242-247.

15. Crozeta BM, Lopes FC, Menezes Silva R, Silva-Sousa YTC, Moretti LF, Sousa-Neto MD. Retreatability of $\mathrm{BC}$ Sealer and AH Plus root canal sealers using new supplementary instrumentation protocol during nonsurgical endodontic retreatment. Clin Oral Investig. $2021 \mathrm{Mar}$;25(3):891-899.

16. Aksel H, Küçükkaya Eren S, Askerbeyli Örs S, Serper A, Ocak M, Çelik HH. Micro-CT evaluation of the removal of root fillings using the ProTaper Universal Retreatment system supplemented by the XP-Endo Finisher file. Int Endod J. 2019 Jul;52(7):1070-1076.

17. Campello AF, Almeida BM, Franzoni MA, Alves FRF, Marceliano-Alves MF, Rôças IN et al. Influence of solvent and a supplementary step with a finishing instrument on filling material removal from canals connected by an isthmus. Int Endod J. 2019 May;52(5):716-724.

18. Volponi A, Pelegrine RA, Kato AS, Stringheta CP, Lopes RT, Silva ASS et al. Micro-computed Tomographic Assessment of Supplementary Cleaning Techniques for Removing Bioceramic Sealer and Gutta-percha in Oval Canals. J Endod. 2020 Dec;46(12):1901-1906.

19. Solomonov M, Paqué F, Kaya S, Adigüzel O, Kfir A, Yiğit-Özer S. Self-adjusting files in retreatment: a high-resolution micro-computed tomography study. J Endod. 2012 Sep;38(9):1283-1287.

20. Yürüker S, Görduysus M, Küçükkaya S, Uzunoğlu E, Ilgın C, Gülen O et al. Efficacy of Combined Use of Different Nickel-Titanium Files on Removing Root Canal Filling Materials. J Endod. 2016 Mar;42(3):487492.

21. Bernardes RA, Duarte MAH, Vivan RR, Alcalde MP, Vasconcelos BC, Bramante CM. Comparison of three retreatment techniques with ultrasonic activation in flattened canals using micro-computed tomography and scanning electron microscopy. Int Endod J. 2016 Sep;49(9):890-897. 
22. Cavenago BC, Ordinola-Zapata R, Duarte MAH, del Carpio-Perochena AE, Villas-Bôas MH, Marciano MA et al. Efficacy of xylene and passive ultrasonic irrigation on remaining root filling material during retreatment of anatomically complex teeth. Int Endod J. 2014 Nov;47(11):1078-1083.

23. Silveira SB, Alves FRF, Marceliano-Alves MF, Sousa JCN, Vieira VTL, Siqueira Jr JF et al. Removal of Root Canal Fillings in Curved Canals Using Either Mani GPR or HyFlex NT Followed by Passive Ultrasonic Irrigation. J Endod. 2018 Feb;44(2):299-303.e1

24. Tavares SJO, Gomes CC, Marceliano-Alves MF, Guimarães LC, Provenzano JC, Amoroso-Silva P et al. Supplementing filling material removal with XP-Endo Finisher R or R1-Clearsonic ultrasonic insert during retreatment of oval canals from contralateral teeth. Aust Endod J. 2020 Oct 8.

25. Shobhana R, Karthick A, Mitthra S, Anuradha B. Application of laser in the field of Endodontics: an update. European Journal of Molecular\&Clinical Medicine 2020; 07:10.

26. Tachinami H., I. Katsuumi. Removal of root canal filling materials using Er: YAG laser irradiation. Dent Mater J. 2010 May;29(3):246-252.

27. Keleş A, Arslan H, Kamalak A, Akçay M, Sousa-Neto MD, Versiani MA. Removal of Filling Materials from Oval-shaped Canals Using Laser Irradiation: A Micro-computed Tomographic Study. J Endod. 2015 Feb;41(2):219-224.

28. Viducić D, Jukić S, Karlović Z, Bozić Z, Miletić I, Anić I, et al. Removal of gutta-percha from root canals using an Nd: YAG laser. Int Endod J. 2003;36(10):670-673.

29. Yu DG, Kimura Y, Tomita Y, Nakamura Y, Watanabe H, Matsumoto K. Study on removal effects of filling materials and broken files from root canals using pulsed Nd:YAG laser. J Clin Laser Med Surg. 2000;18(1):2328.

\section{Corresponding author:}

Dr. Sherihan Zongova-Adem,

Center of Integrated Dental Medicine, Faculty of Dental Medicine, Medical University, Sofia;

01, St. Georgi Sofiiski blvd., 1431 Sofia, Bulgaria.

Tel: +359 895782414,

E-mail: dr.zongova@gmail.com 